\title{
Hydrogen sulfide: role in ion channel and transporter modulation in the eye
}

\author{
Ya F. Njie-Mbye ${ }^{1 *}$, Catherine A. Opere ${ }^{2}$, Madhura Chitnis ${ }^{1}$ and Sunny E. Ohia ${ }^{1}$ \\ 1 Department of Pharmaceutical Sciences, College of Pharmacy and Health Sciences, Texas Southern University, Houston, TX, USA \\ 2 Department of Pharmacy Sciences, School of Pharmacy and Health Professions, Creighton University, Omaha, NE, USA
}

\author{
Edited by: \\ Mike Althaus, Justus-Liebig \\ University of Giessen, Germany \\ Reviewed by: \\ Martin Diener, University Giessen, \\ Germany \\ Hideo Kimura, National Institute of \\ Neuroscience, Japan \\ *Correspondence: \\ Ya F. Njie-Mbye, Department of \\ Pharmaceutical Sciences, College of \\ Pharmacy and Health Sciences, \\ Texas Southern University, \\ 3100 Cleburne Street, Houston, \\ TX 77004, USA. \\ e-mail:njiey@tsu.edu
}

Hydrogen sulfide $\left(\mathrm{H}_{2} \mathrm{~S}\right)$, a colorless gas with a characteristic smell of rotten eggs, has been portrayed for decades as a toxic environmental pollutant. Since evidence of its basal production in mammalian tissues a decade ago, $\mathrm{H}_{2} \mathrm{~S}$ has attracted substantial interest as a potential inorganic gaseous mediator with biological importance in cellular functions. Current research suggests that, next to its counterparts nitric oxide and carbon monoxide, $\mathrm{H}_{2} \mathrm{~S}$ is an important multifunctional signaling molecule with pivotal regulatory roles in various physiological and pathophysiological processes as diverse as learning and memory, modulation of synaptic activities, cell survival, inflammation, and maintenance of vascular tone in the central nervous and cardiovascular systems. In contrast, there are few reports of a regulatory role of $\mathrm{H}_{2} \mathrm{~S}$ in the eye. Accumulating reports on the pharmacological role of $\mathrm{H}_{2} \mathrm{~S}$ in ocular tissues indicate the existence of a functional trans-sulfuration pathway and a potential physiological role for $\mathrm{H}_{2} \mathrm{~S}$ as a gaseous neuromodulator in the eye. Thus, understanding the role of $\mathrm{H}_{2} \mathrm{~S}$ in vision-related processes is imperative to our expanding knowledge of this molecule as a gaseous mediator in ocular tissues. This review aims to provide a comprehensive and current understanding of the potential role of $\mathrm{H}_{2} \mathrm{~S}$ as a signaling molecule in the eye. This objective is achieved by discussing the involvement of $\mathrm{H}_{2} \mathrm{~S}$ in the regulation of (1) ion channels such as calcium (L-type, T-type, and intracellular stores), potassium (K $\mathrm{K}_{\text {ATP }}$ and small conductance channels) and chloride channels, (2) glutamate transporters such as EAAT1/GLAST and the L-cystine/glutamate antiporter. The role of $\mathrm{H}_{2} \mathrm{~S}$ as an important mediator in cellular functions and physiological processes that are triggered by its interaction with ion channels/transporters in the eye will also be discussed.

\footnotetext{
Keywords: cystine/glutamate antiporter, EAAT/GLAST transporter, hydrogen sulfide, ion channels, ocular tissues, cysteine transporter
}

\section{INTRODUCTION}

The potential role of hydrogen sulfide $\left(\mathrm{H}_{2} \mathrm{~S}\right)$ as a regulatory mediator has stimulated a surge of interest in its biological significance in cellular functions in the human body. This colorless gas, known for decades only as a toxic environmental pollutant has been found to be produced in substantial amounts in mammalian tissues. The endogenous production of $\mathrm{H}_{2} \mathrm{~S}$ in mammalian tissues is dependent on the activity of two pyridoxal-5'-phosphate dependent-enzymes, cystathionine $\beta$-synthase (CBS; EC 4.2.1.22) and cystathionine $\gamma$-lyase (CSE; EC 4.4.1.1). Both CBS and CSE are enzymes of the trans-sulfuration pathway that inter-converts L-methionine and L-cysteine but can also use L-cysteine as an alternative substrate to form $\mathrm{H}_{2} \mathrm{~S}$ (Stipanuk and Beck, 1982; Erickson et al., 1990; Swaroop et al., 1992). Recently, a newly identified enzyme, 3-mercaptopyruvate sulfurtransferase (3MST), has been reported to be involved in the production of $\mathrm{H}_{2} \mathrm{~S}$ (Shibuya et al., 2009a,b). Current biomedical research suggest that $\mathrm{H}_{2} \mathrm{~S}$ is an important gasotransmitter in mammals, and is involved in several physiological and pathophysiological processes as diverse as learning and memory, inflammation, and the regulation of blood pressure (Abe and Kimura, 1996; Lowicka and Beltowski, 2007). In the cardiovascular system, $\mathrm{H}_{2} \mathrm{~S}$ has been shown to play a pivotal role in maintenance of vascular tone (Hosoki et al., 1997; Zhao et al., 2001; Cheng et al., 2004; Webb et al., 2008) whereas in the central nervous system (CNS) this gas was found to exert a neuroprotective role on neurons and exhibit neurotransmitterlike function in the modulation of synaptic activities (Zhao et al., 2001; Kimura, 2002; Kimura et al., 2005, 2006; Szabo, 2007; Qu et al., 2008; Webb et al., 2008). Many of the cellular effects of $\mathrm{H}_{2} \mathrm{~S}$ in the vasculature and brain have been reported to be mediated by ion channels and transporters.

There is ample evidence that $\mathrm{H}_{2} \mathrm{~S}$ targets different ion channels to modulate varied physiological functions. Extensive studies in the vasculature and CNS demonstrate that $\mathrm{H}_{2} \mathrm{~S}$ interacts with ion channels such as ATP-sensitive potassium $\left(\mathrm{K}_{\mathrm{ATP}}\right)$ channels, calcium $\left(\mathrm{Ca}^{2+}\right)$ and chloride $\left(\mathrm{Cl}^{-}\right)$channels to regulate vascular tone, and exert its neurotransmitter and neuroprotective-like properties (Kimura and Kimura, 2004; Tang et al., 2010). In addition, there is evidence that the neuromodulatory role of $\mathrm{H}_{2} \mathrm{~S}$ in cellular functions and physiological processes are triggered by 
its interaction with several transporter systems. $\mathrm{H}_{2} \mathrm{~S}$ has been reported to enhance the activity of transporters, thereby facilitating the release of antioxidants that are essential for neuronal protection against excitotoxic damage (Lu et al., 2008; Kulkarni et al., 2009; Kimura, 2011a,b). Furthemore, through its interaction with transporters, $\mathrm{H}_{2} \mathrm{~S}$ plays an important role in maintaining the redox balance and thus serves both as a neuroprotectant and neuromodulator.

In contrast to the central nervous and cardiovascular systems, there are few reports of the involvement of $\mathrm{H}_{2} \mathrm{~S}$ in the regulation of ion channels and transporters in the eye. Given the important modulatory effects of $\mathrm{H}_{2} \mathrm{~S}$ on different ion channels and transporter systems in cellular functions and disease conditions in the central nervous and cardiovascular systems, there is a great need for studies centered on the potential role of $\mathrm{H}_{2} \mathrm{~S}$ as a signaling molecule in ocular tissues. Indeed, we have evidence that $\mathrm{H}_{2} \mathrm{~S}$ can induce pharmacological effects in mammalian ocular tissues, alter sympathetic and glutamatergic neurotransmission, and play a regulatory role in signal transduction processes in the eye (Monjok et al., 2008; Opere et al., 2009; Njie-Mbye et al., 2010; Ohia et al., 2010). The presence of CBS and CSE, the biosynthetic enzymes for $\mathrm{H}_{2} \mathrm{~S}$ have also been reported in several ocular tissues, (Persa et al., 2006; Pong et al., 2007) indicating the existence of a functional trans-sulfuration pathway and a potential physiological role for $\mathrm{H}_{2} \mathrm{~S}$ as a gaseous neuromodulator in the eye. Understanding the regulatory role of $\mathrm{H}_{2} \mathrm{~S}$ in ion channel and transporter modulation in the eye is critical to our expanding knowledge of this gasotransmitter in ocular neuropathies. In this review article we will discuss the interaction of $\mathrm{H}_{2} \mathrm{~S}$ with different types of ion channels and transporter systems found in the eye. Our attention will be particularly devoted on the role of $\mathrm{H}_{2} \mathrm{~S}$ as a molecule able to trigger cell signaling in ocular tissues.

\section{HYDROGEN SULFIDE AND THE EYE}

Evidence from literature supports the presence of a functional trans-sulfuration pathway and a potential physiological/ pharmacological relevance for $\mathrm{H}_{2} \mathrm{~S}$ in the mammalian eye (De et al., 1974; Persa et al., 2006; Pong et al., 2007; Kulkarni et al., 2011). CBS and CSE, the primary enzymes of the transsulfuration pathway have been localized in mammalian ocular tissues (De et al., 1974; Persa et al., 2006; Pong et al., 2007). Moreover, deficiency of CBS has been linked to ocular disorders such as lens dislocation, retina degeneration, retinal detachment and acute glaucoma, (Kraus and Kozich, 2001) suggesting a physiological significance for this pathway in ocular tissues. Further support for a physiological relevance of $\mathrm{H}_{2} \mathrm{~S}$ in mammalian ocular tissues was provided by us when we demonstrated the endogenous production of $\mathrm{H}_{2} \mathrm{~S}$ in bovine ocular tissues (Kulkarni et al., 2011). Interestingly, the magnitude of $\mathrm{H}_{2} \mathrm{~S}$ content corresponded to the reported expression of CBS and CSE enzymes in ocular tissues (De et al., 1974; Persa et al., 2006; Pong et al., 2007). In bovine retina, both CSE and CBS antagonists, propargyglycine (PAG), and aminooxyacetic acid (AOA) attenuated while the CBS stimulator, S-adenosyl-L-methionine (SAM) enhanced endogenous production of $\mathrm{H}_{2} \mathrm{~S}$, (Kulkarni et al., 2011) corroborating the involvement of these trans-sulfuration pathway enzymes in the production of $\mathrm{H}_{2} \mathrm{~S}$ in retina. In addition to its in situ production, there is evidence supporting a pharmacological role for this gasotransmitter in mammalian ocular tissues (Figure 1). In the anterior uvea, we observed an inhibitory action of $\mathrm{H}_{2} \mathrm{~S}$ (using sodium hydrosulfide, NaHS, and/or sodium sulfide, $\mathrm{Na}_{2} \mathrm{~S}$ as donors) on both electrically evoked $\left[{ }^{3} \mathrm{H}\right] \mathrm{NE}$ (norepinephrine) release and endogenous catecholamine concentrations in porcine iris-ciliary body in a concentration-dependent manner (Kulkarni et al., 2009). The inhibitory action of $\mathrm{H}_{2} \mathrm{~S}$ donors on NE release was reversed by CBS and CSE antagonists, AOA and PAG respectively, suggesting that $\mathrm{H}_{2} \mathrm{~S}$ attenuates sympathetic neurotransmission from isolated porcine anterior uvea by an effect that is partially dependent on its intramural biosynthesis. Moreover, $\mathrm{H}_{2} \mathrm{~S}$ donors may exert their inhibitory action on sympathetic neurotransmission by a direct effect of this gasotransmitter on endogenous neurotransmitter release (Kulkarni et al., 2009). In another study, $\mathrm{H}_{2} \mathrm{~S}$ donors exhibited an inhibitory action on carbachol-induced tone in isolated porcine irides that was dependent on endogenous production of prostanoids and the biosynthesis of $\mathrm{H}_{2} \mathrm{~S}$ by CBS (Monjok et al., 2008). Whereas the nitric oxide (NO) synthase inhibitor, N (G)-nitro-L- arginine methyl ester (L-NAME) had no effect, the $\mathrm{K}_{\text {ATP }}$ channel inhibitor, glibenclamide (100 and $300 \mu \mathrm{M})$, blocked relaxations induced by NaHS, suggesting the involvement of $\mathrm{K}_{\mathrm{ATP}}$ channels on the $\mathrm{H}_{2} \mathrm{~S}$ on response in the anterior uvea (Monjok et al., 2008). In porcine irides, we observed an inhibitory action of L-cysteine $\left(\mathrm{H}_{2} \mathrm{~S}\right.$ substrate) that was dependent upon the endogenous production of $\mathrm{H}_{2} \mathrm{~S}$ by CBS and CSE and was mediated by prostanoids and $\mathrm{K}_{\mathrm{ATP}}$ channels (Ohia et al., 2010). Taken together, these data support a pharmacological role for $\mathrm{H}_{2} \mathrm{~S}$ in the anterior uvea. So far, the potential therapeutic implications of the action of $\mathrm{H}_{2} \mathrm{~S}$ in these tissues have not been fully elucidated. In preliminary studies, $\mathrm{H}_{2} \mathrm{~S}$ donors reduced intraocular pressure (IOP) in normotensive rabbits (Ohia et al., US Patent \#8,092,838, Jan 10, 2012). Similarly, the $\mathrm{H}_{2} \mathrm{~S}$-hybrid molecule ACS67 significantly reduced IOP in glaucomatous rabbits (Perrino et al., 2009) suggesting a potential application for $\mathrm{H}_{2} \mathrm{~S}$ in the regulation of IOP. In spite of these findings, the exact role of the transsulfuration pathway in the anterior uvea and the mechanisms by which $\mathrm{H}_{2} \mathrm{~S}$ regulates IOP remain unknown and merit further investigation.

In addition to the anterior uvea, pharmacological actions have been reported for $\mathrm{H}_{2} \mathrm{~S}$ in mammalian retina as well (Figure 1). $\mathrm{H}_{2} \mathrm{~S}$ donors inhibited amino acid neurotransmission from both isolated bovine and porcine retina by an effect that was dependent, at least in part, on intramural biosynthesis of $\mathrm{H}_{2} \mathrm{~S}$ (Opere et al., 2009). Moreover, the gasotransmitter enhanced cyclic AMP production in bovine and porcine isolated neural retina and retinal pigment epithelial (RPE)-J cells by mechanisms that were dependent on biosynthesis of $\mathrm{H}_{2} \mathrm{~S}$ by CBS and CSE and partially dependent on activation of the $\mathrm{K}_{\mathrm{ATP}}$ channels (Njie-Mbye et al., 2010, 2012). Because an increase in retinal glutamate concentrations has been linked to retinal excitotoxicty, the ability of $\mathrm{H}_{2} \mathrm{~S}$ to reduce glutamate release suggest a potential neuroprotective action in retinal neurons. Several investigators have since confirmed the neuroprotective effect of $\mathrm{H}_{2} \mathrm{~S}$ in retina (Biermann et al., 2011; Mikami et al., 2011). Indeed, $\mathrm{H}_{2} \mathrm{~S}$ donors protected mice retinal neurons from light-induced degeneration 


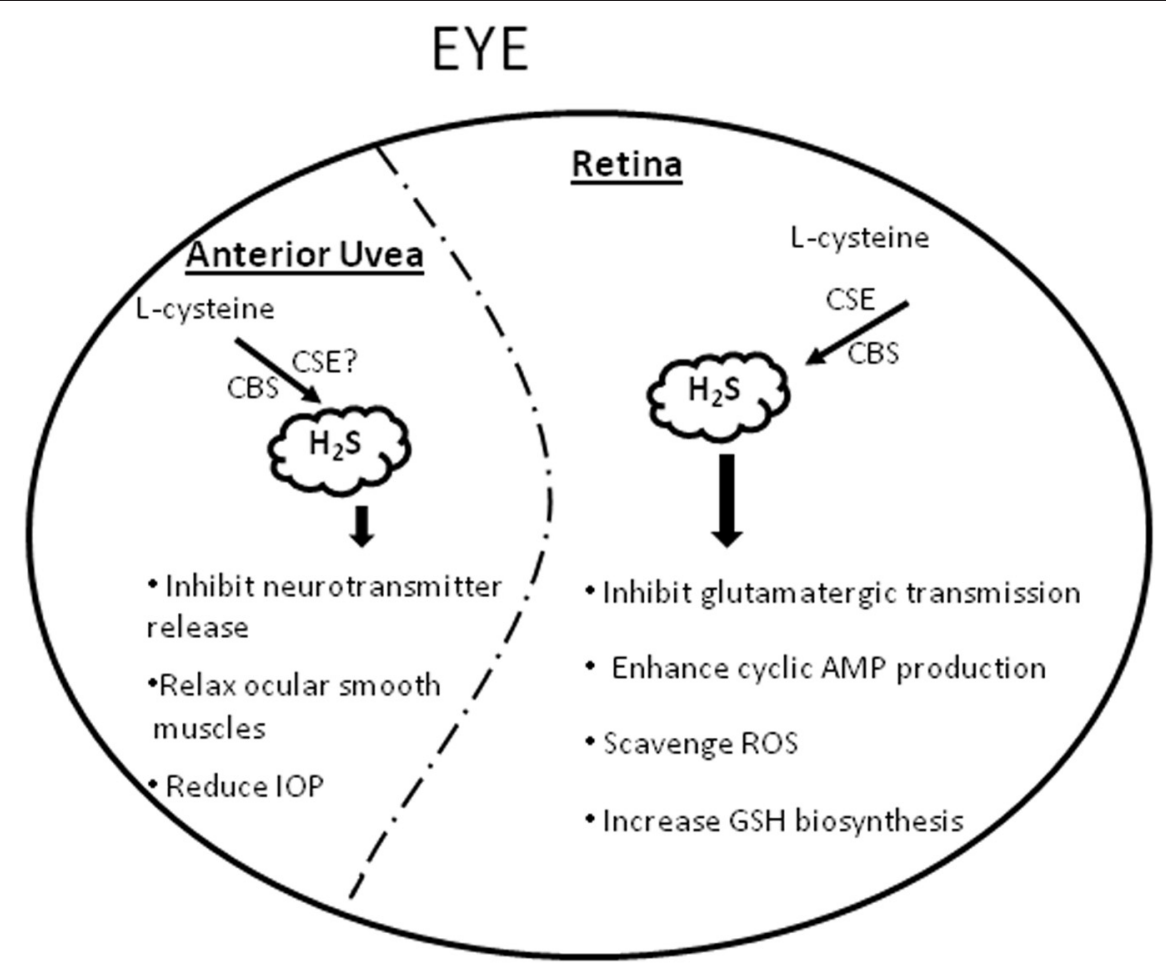

FIGURE 1 | A schematic representation summarizing the physiological and pharmacological effects of $\mathrm{H}_{2} \mathrm{~S}$ in the eye. GSH $=$ glutathione, $\mathrm{ROS}=$ Reactive oxygen species, IOP $=$ intraocular pressure.

(Mikami et al., 2011). Similarly, $\mathrm{H}_{2} \mathrm{~S}$ preconditioning conferred to protection of rat retina exposed to ischemia reperfusion injury (Biermann et al., 2011). The $\mathrm{H}_{2}$ S-hybrid, ACS67 increased reduced glutathione levels, suggesting a potential neuroprotective role for this $\mathrm{H}_{2} \mathrm{~S}$-donor (Osborne et al., 2010). It is now apparent that $\mathrm{H}_{2} \mathrm{~S}$ plays a dual role in biological tissues, being cytotoxic at higher and cytoprotective at lower concentrations of the gas (Martelli et al., 2010). The latter action, which has been demonstrated in various cell types and neurons, (Kimura et al., 2006; Sivarajah et al., 2006; Elrod et al., 2007) is partially ascribed to its ability to scavenge several reactive oxygen species (e.g., such as superoxide radical anion, hydrogen peroxide, peroxynitrie and hypochlorite) and increase GSH biosynthesis (Martelli et al., 2010). Several questions remain to be addressed, such as the role of molecular targets of $\mathrm{H}_{2} \mathrm{~S}$ such as $\mathrm{K}_{\text {ATP }}$ channels in its neuroprotective action of $\mathrm{H}_{2} \mathrm{~S}$; integration of the trans-sulfuration pathway in retinal neurotransmitter pathways; interaction of $\mathrm{H}_{2} \mathrm{~S}$ and transporters and other ion channels in the eye. Based upon the known pharmaocological role and protective mechanisms of $\mathrm{H}_{2} \mathrm{~S}$ in biological systems, it is conceivable that $\mathrm{H}_{2} \mathrm{~S}$ could find a significant application in ocular neuropathies, thereby opening up new molecular targets for management of ocular diseases.

\section{REGULATION OF ION CHANNELS BY $\mathrm{H}_{2} \mathrm{~S}$ IN THE EYE CALCIUM CHANNELS $\left(\mathrm{Ca}^{2+}\right)$ IN OCULAR TISSUES}

Calcium $\left(\mathrm{Ca}^{2+}\right)$ is an essential ion that is involved in the regulation of several processes in the body such as signal transduction pathways, contraction, secretion, blood coagulation, gene expression, apoptosis, necrosis, cell division, and endocytocis (Williams, 1974; Shuttleworth, 1997; Berridge, 2005; Carafoli, 2005; Wimmers et al., 2007). Within the cell, free intracellular $\left[\mathrm{Ca}^{2+}\right]_{\mathrm{I}}$ content is tightly regulated at about $100 \mathrm{nM}$ to maintain a steep inwardly directed concentration and electrochemical gradients across the cell membrane by an interplay of several $\mathrm{Ca}^{2+}$ channels, pumps, transporters, buffering systems and intracellular storage organelles (Bogeski et al., 2011). Several ion channels facilitate transmission of $\left[\mathrm{Ca}^{2+}\right]$ ions across the membranes: the voltage-gated calcium channels (CaV), transient receptor potential (TRP) ion channels, transmitter-gated $\mathrm{Ca}^{2+}$ permeant ion channels and the store operated $\mathrm{Ca}^{2+}$ entry (SOCE) and $\mathrm{Ca}^{2+}$ released-activated $\mathrm{Ca}^{2+}$ (CRAC/Orai) channels (Bogeski et al., 2011). Although various potential molecular targets for calcium channels have been identified, only the L-type voltage-activated calcium channels have found wide therapeutic beneficial application. There is evidence in the eye for the existence of a calcium transport system. $\mathrm{Ca}^{2+}$ has been reported to play a key role in mammalian lens physiology and pathology. Excessive levels of $\mathrm{Ca}^{2+}$ have been implicated in cortical cataract and there is presence of $\mathrm{Ca}^{2+}$ linked receptors in the lens (Rhodes and Sanderson, 2009). Voltage-gated $\mathrm{Ca}^{2+}$ channels: transient (T-type) and dihydropyridine-sensitive longlasting (L-type) channels, have been reported to be expressed in muller cells of the retina (Puro and Mano, 1991; Puro et al., 1996; Bringmann et al., 2000). The retinal pigment epithelium (RPE) has also been reported to expresses voltage- and ligand-gated $\mathrm{Ca}^{2+}$ conducting channels (Wimmers et al., 2007). These channels 
act as regulators of secretory activity, and thus contribute to RPE function. Changes in $\mathrm{Ca}^{2+}$ channel function, or activity has been shown to lead to degenerative diseases of the retina (Wimmers et al., 2007).

\section{EFFECTS OF $\mathrm{H}_{2} \mathrm{~S}$ ON CALCIUM CHANNELS $\left(\mathrm{Ca}^{2+}\right.$ ) IN OCULAR TISSUES} Despite the implication of $\mathrm{Ca}^{2+}$ in ocular physiology and pathology, there is a great need for studies centered on the regulatory role of $\mathrm{H}_{2} \mathrm{~S}$ and its interaction with calcium channels. Only one study to date, has addressed the possible interaction of $\mathrm{H}_{2} \mathrm{~S}$ and $\mathrm{Ca}^{2+}$ channels in the eye. In this study the authors' report that the production of $\mathrm{H}_{2} \mathrm{~S}$ in retinal neurons is regulated by intracellular $\mathrm{Ca}^{2+}$, (Mikami et al., 2011) and in turn $\mathrm{H}_{2} \mathrm{~S}$ can suppress $\mathrm{Ca}^{2+}$ channels by activating vacuolar type $\mathrm{H}^{+}$-ATPase (V-ATPase). Furthermore, the study also demonstrated that $\mathrm{H}_{2} \mathrm{~S}$ can suppress the elevation of $\mathrm{Ca}^{2+}$ in photoreceptor cells by activating V-ATPase in horizontal cells and thus maintain $\mathrm{Ca}^{2+}$ homeostasis. From these observations, the authors conclude that $\mathrm{H}_{2} \mathrm{~S}$ protects photoreceptor cells from the insult caused by excessive levels of light. Clearly results from this study provides a new insight into the regulation of $\mathrm{H}_{2} \mathrm{~S}$ production and the modulatory interaction of $\mathrm{H}_{2} \mathrm{~S}$ and $\mathrm{Ca}^{2+}$ channels in retinal transmission. In addition, the study postulates a cytoprotective effect of $\mathrm{H}_{2} \mathrm{~S}$ on retinal neurons and provides a basis for the therapeutic target for retinal degeneration. Increasing knowledge about the properties of $\mathrm{Ca}^{2+}$ channels in ocular tissuess especially the retina will not only provide a new understanding of ocular function but could also provide a better understanding of the role of $\mathrm{H}_{2} \mathrm{~S}$ in ocular health and vision.

\section{POTASSIUM $\left(\mathrm{K}^{+}\right)$CHANNELS IN OCULAR TISSUES}

Potassium ion $\left(\mathrm{K}^{+}\right)$channel family represents one of the most prominent and ubiquitous ion channels in living organisms where their physiological role range from regulation of the action potentials in excitable cells to regulation of transepithelial transport processes, intracellular $\mathrm{pH}$, cell survival and growth factor secretion in non-excitable cells (Ashcroft and Gribble, 1999; Bauer et al., 1999; MacDonald and Wheeler, 2003; Warth, 2003; Masi et al., 2005). $\mathrm{K}^{+}$channel family consists of four subfamilies, the inwardly rectifying $\mathrm{K}^{+}\left(\mathrm{K}_{\mathrm{ir}}\right)$-channels, voltage-gated $\mathrm{K}^{+}$channels, $\mathrm{Ca}^{2+}$-activated $\mathrm{K}^{+}$channels, and two-pore or leak $\mathrm{K}^{+}$-channels that are classified based upon number of transmembrane domains and electrophysiological properties. In the eye, $\mathrm{K}^{+}$channels play central roles in maintaining ion, fluid balance and membrane potential. Several $\mathrm{K}^{+}$channel subtypes such as voltage-gated $\mathrm{K}^{+}(\mathrm{Kv})$ channels and 4-aminopyridine (4AP)-sensitive $\mathrm{K}^{+}$channels are expressed in mammalian corneal epithelial cells (Rae, 1985; Rae et al., 1990; Rae and Farrugia, 1992). Studies have shown that changes in $\mathrm{K}^{+}$channel activity modulate essential corneal epithelial functions needed for tissue homeostasis (Wolosin and Candia, 1987; Klyce and Wong, 1977). Furthermore, emerging evidence suggest that $\mathrm{K}^{+}$channels play a crucial role in controlling apoptosis and proliferation in corneal epithelial cells (Lu et al., 2003; Roderick et al., 2003). Three major potassium currents (an outwardly rectifying current, an inwardly rectifying current, and a calcium-activated current) have been characterized in several mammalian lens epithelial cells
(Rae, 1986; Cooper et al., 1991). These potassium conductances are essential for the maintenance of lens volume and transparency. Inwardly rectifying potassium (Kir) channel was reported to be highly expressed in bovine and human trabecular meshwork cells, (Llobet et al., 2001) as well as muller glial cells of the retina (Kofuji et al., 2002). $\mathrm{K}^{+}$channels (Kv11; ether à-go-go related gene; erg) belonging to the family of voltage-gated $\mathrm{K}^{+}$channels are present in mouse and human retina with the most abundant expression in rod bipolar cells. These channels are also found in the inner and outer plexiform layer, inner segments of photoreceptors, as well as the retina pigment epithelium (Cordeiro et al., 2011). These channels are vital for the control of the membrane potential in retinal neurons. Given the importance of $\mathrm{K}^{+}$channel modulation in ocular tissues, evidence of an interaction between $\mathrm{H}_{2} \mathrm{~S}$ and these channels in the eye is imperative for understanding the role of $\mathrm{H}_{2} \mathrm{~S}$ as a signaling molecule in ocular functions.

\section{EFFECTS OF $\mathrm{H}_{2} \mathrm{~S}$ ON POTASSIUM $\left(\mathrm{K}^{+}\right)$CHANNELS IN OCULAR TISSUES}

The pharmacological effects of $\mathrm{H}_{2} \mathrm{~S}$ in the vasculature and brain, has been reported to involve $\mathrm{K}^{+}$channels. To the best of our knowledge there are no studies in the literature pertaining to the effects of $\mathrm{H}_{2} \mathrm{~S}$ on $\mathrm{K}^{+}$channels in the eye, except for those generated from our laboratory. In previous studies we have demonstrated that the pharmacological effects of $\mathrm{H}_{2} \mathrm{~S}$ (using $\mathrm{H}_{2} \mathrm{~S}$-releasing compounds) in ocular tissues are partly mediated by $\mathrm{K}_{\text {ATP }}$ channels (Monjok et al., 2008; Kulkarni et al., 2009; Opere et al., 2009; Ohia et al., 2010). With the use of specific channel blockers, we report that $\mathrm{H}_{2} \mathrm{~S}$ interacts with $\mathrm{K}_{\text {ATP }}$ channels to relax ocular smooth muscle, and alter sympathetic and glutamergic neurotransmission in the anterior uvea and retina (Monjok et al., 2008; Kulkarni et al., 2009; Opere et al., 2009; Ohia et al., 2010). Furthermore, we recently show that $\mathrm{K}_{\mathrm{ATP}}$ channels are involved in the regulatory role of $\mathrm{H}_{2} \mathrm{~S}$ in signal transduction processes in retina pigment epithelium cells (Njie-Mbye et al., 2012). It is reported that $\mathrm{K}^{+}$channels play vital roles in cellular functions including vascular tone regulation, mediating neurotransmitter release, and neuroprotection in cardiovascular and CNSs (Yamada and Inagaki, 2005). Thus it is tempting to speculate a physiological role of $\mathrm{H}_{2} \mathrm{~S}$ in ocular tissues that involves the activation of $\mathrm{K}^{+}$channels.

\section{CHLORIDE $\left(\mathrm{Cl}^{-}\right)$CHANNELS IN OCULAR TISSUES}

Chloride $\left(\mathrm{Cl}^{-}\right)$is one of the most prominent anions in the body that is involved in the regulation of a variety of important physiological and cellular functions such as volume homeostasis, organic solute transport, cell migration, cell proliferation, cell differentiation, and apoptosis. Unlike most physiological ions whose levels are tightly regulated within a limited range, the resting $\mathrm{Cl}^{-}$ ion concentration varies in different mammalian cell types and in developing cells (Wimmers et al., 2007). $\mathrm{Cl}^{-}$conductance across membranes is facilitated by several pumps and co-transporters that are localized in plasma membranes and membranes of intracellular organelles. For example, chloride influx is facilitated by the $\mathrm{Na}^{+} / \mathrm{K}^{+} / \mathrm{Cl}^{-}$co-transporters, $\mathrm{Cl}^{-} / \mathrm{HCO}_{3}$-exchangers, and $\mathrm{Na}^{+} /-\mathrm{Cl}^{-}$co-transporters while efflux is achieved by the cell $\mathrm{K}^{+} /$$\mathrm{Cl}^{-}$co-transporters and $\mathrm{Na}^{+}$-dependent $\mathrm{Cl}^{-} / \mathrm{HCO}_{3}$ - exchanger. Other channels and transporters expressed in intracellular 
membranes as well as $\mathrm{Cl}^{-}$-binding proteins regulate intravesicular $\mathrm{pH}$ and $\mathrm{Cl}^{-}$concentration (Duran et al., 2010). Several channels mediate passive flow of $\mathrm{Cl}^{-}$ions across membranes. With exception of the transmitter-gated GABA and glycine receptors, these $\mathrm{Cl}^{-}$channels are broadly classified into five subfamilies, the voltage-sensitive $\mathrm{ClC}$ subfamily, calcium-activated channels, high- (maxi) conductance channels, the cystic fibrosis transmembrane conductance regulator (CFTR) and volumeregulated channels (Verkman and Galietta, 2009). So far, only the voltage-sensitive $\mathrm{ClC}$ subfamily, CFTR and the transmittergated channels have been well described. In general, $\mathrm{Cl}^{-}$channels are fairly non-selective for inorganic ions. Dysfunctional $\mathrm{Cl}^{-}$ channels have been linked to channelopathies such as myotonia congenita and cystic fibrocis (Duran et al., 2010). $\mathrm{Cl}^{-}$channels are more abundantly expressed in the anterior segment of the eye due to $\mathrm{Cl}^{-}$being the principal anion of aqueous humor secretion. Studies show that chloride efflux plays an important role in aqueous humor production and chloride channels present in the ocular ciliary epithelium are involved in aqueous humor homeostasis. Chloride currents have been reported to be present in bovine non-pigmented ciliary epithelium (NPE) and in transformed cultured human NPE (Chen and Sears, 1997). High-(maxi) conductance chloride channels are expressed in ciliary pigmented epithelial (PE) cells, (Do et al., 2004) whilst cAMP-activated $\mathrm{Cl}^{-}$channels are present in the basolateral membrane of nonpigmented (NPE) ciliary epithelium (Edelman et al., 1995). CFTR is functionally expressed in corneal and conjunctival epithelium, corneal endothelium, and RPE (Shiue et al., 2002; Sun and Bonanno, 2002; Turner et al., 2002; Blaug et al., 2003; Levin and Verkman, 2005; Reigada and Mitchell, 2005). CFTR expression patterns in these tissues suggest the involvement of these chloride channels in regulation of tear film volume, corneal hydration and transparency, aqueous humor volume and IOP, and subretinal compartment size and ionic composition. In the retina, several $\mathrm{Cl}^{-}$transporter and channels including the $\mathrm{Na}^{+} / \mathrm{K}^{+} / \mathrm{Cl}^{-}$cotransporters, CFTR, and the voltage-sensitive $\mathrm{ClC}$ subfamily were reported to be highly expressed in the pigment epithelial layer (Zhang et al., 2011).

\section{EFFECT OF $\mathrm{H}_{2} \mathrm{~S}$ ON CHLORIDE (CI-) CHANNELS IN OCULAR TISSUES}

The activation of $\mathrm{Cl}^{-}$channels by $\mathrm{H}_{2} \mathrm{~S}$ in the CNS has been shown as a protective mechanism for neurons from oxytosis (Tang et al., 2010). Electrophysiological evidence demonstrates that $\mathrm{H}_{2} \mathrm{~S}$ interacts with Cl- channels in the vasculature (Tang et al., 2010). To the best of our knowledge there are no studies reporting the interaction of $\mathrm{H}_{2} \mathrm{~S}$ with $\mathrm{Cl}^{-}$channels in the eye. The observation of the presence of chloride channels in ocular tissues especially in the anterior uvea, coupled with evidence of channel activation by $\mathrm{H}_{2} \mathrm{~S}$ in non-ocular tissues, suggest possible regulation of chloride fluxes by $\mathrm{H}_{2} \mathrm{~S}$ in the eye with neuroprotective consequences and IOP lowering effects.

\section{REGULATION OF TRANSPORTERS BY $\mathrm{H}_{2} \mathrm{~S}$ IN THE EYE EXCITATORY AMINO ACID TRANSPORTER/GLUTAMATE ASPARTATE TRANSPORTER (EAAT/GLAST) IN OCULAR TISSUES}

Glutamate is the major excitatory neurotransmitter in the mammalian CNS. Under normal physiological conditions, extracellular glutamate is tightly regulated (resting levels $\leq 1 \mu \mathrm{M}$ ) by five distinct excitatory amino acid transporters, EAAT1 (glutamate/aspartate transporter [GLAST]); EAAT2 (glutamate carrier [GLT-1]), EAAT3 (excitatory amino acid carrier 1 [EAAC1]), EAAT4 and EAAT5 (Zerangue and Kavanaugh, 1996; Levy et al., 1998). Excessive extracellular glutamate is known to lead to excitotoxicty in neuronal tissues. Thus, EAAT transporters play the essential role of rapidly terminating synaptic transmission, maintaining low ambient extracellular glutamate while simultaneously conserving neuronal glutamate for reuse via the glutamateglutamine cycling system (Copenhagen et al., 2002; Zou and Crews, 2005). Glutamate transporter uptake activity is accompanied by a net inward movement of positive ions $\left(3 \mathrm{Na}^{+}: 1 \mathrm{H}^{+}\right.$ co-transport versus $\mathrm{K}^{+}$counter-transport) (Kanner, 2006) and could be coupled to Na, K-ATPase pump (Rose et al., 2009). Glutamate transporters exhibit differential distribution in different tissues. In the mammalian retina, using immunocytochemical studies, EAAT1 (GLAST) has been shown to be localized in Muller cells (Rauen et al., 1996; Pow and Barnett, 1999). EAAT2 have been identified in cone photoreceptor and bipolar cells (Rauen and Kanner, 1994) while EAAT3 (EAAC1) in inner retinal neurons (Rauen et al., 1996). EAAT4 is localized in retinal astrocytes (Ward et al., 2004) and EAAT5 in photoreceptors, bipolar cells and in some muller cells (Arriza et al., 1997; Pow and Barnett, 2000). Interestingly, EAAT5 is found exclusively in retina (Pow and Barnett, 2000). The sodium-dependent glutamate-aspartate transporter (GLAST or EAAT1) is the major glutamate transporter in muller cells. This glutamate transporter (EAAT1/GLAST) maintains extracellular glutamate at a low level to ensure a high signal-to-noise ratio for glutamatergic neurotransmission and thus shield neurons from excitotoxic damage. To the best of our knowledge there are no studies till date that have examined the effect of $\mathrm{H}_{2} \mathrm{~S}$ on glutamate transporter in ocular tissues. Only one study, by our laboratory has demonstrated that $\mathrm{H}_{2} \mathrm{~S}$ donors caused an attenuation of glutamatergic transmission in mammalian retinae (Opere et al., 2009). Although the exact mechanism of action is not clear, it is feasible that $\mathrm{H}_{2} \mathrm{~S}$ donors could decrease glutamatergic transmission in mammalian retinae due to involvement of EAAT.

\section{CYSTINE/GLUTAMATE ANTIPORTER (SYSTEM $\mathrm{X}_{\mathrm{C}}^{-}$) IN OCULAR TISSUES}

The cystine/glutamate antiporter (System $\mathrm{x}_{\mathrm{C}}^{-}$) is responsible for the $\mathrm{Na}^{+}$independent electroneutral exchange of cystine and glutamate. It is a member of the heteromeric amino acid transporter family which is composed of a heavy subunit and a corresponding light subunit linked by a disulfide bridge (Lim and Donaldson, 2011). System $x_{C}^{-}$is regulated by extra- and intracellular gradients of glutamate which drives the import of cystine coupled to export of glutamate (Fiorucci et al., 2006; Lowicka and Beltowski, 2007). System $x_{C}^{-}$has two major functions. First, it mediates cellular uptake of cystine for the maintenance of intracellular levels of glutathione, essential for protection of cells from oxidative stress. Second, it is instrumental in maintaining the redox balance between extracellular cystine and cysteine (Lo et al., 2008). In the eye, system $\mathrm{x}_{\mathrm{C}}^{-}$has been identified in veterbrate lens) (Lim et al., 2005) and different parts of the mamamlian retina including 
the retinal endothelial cells, outer plexiform of retina, muller cells, retinal pigment cells and retinal ganglion (Kato et al., 1993; Bridges et al., 2001; Hosoya et al., 2002; Tomi et al., 2002; Dun et al., 2006). Oxidative damage of proteins is believed to underlie several major eye diseases such as age related nuclear (ARN) cataract, age related macular degeneration (AMD) and diabetic retinopathy (Lo et al., 2008). GSH, a major and potent antioxidant in the cells may prevent or slow down the progression of such diseases by protecting the thiol groups of proteins and minimizing oxidation-induced protein aggregation formation. However, oxidative stress alters rate of conversion of cysteine to glutathione and leads to depletion of glutathione levels (Fiorucci et al., 2006). System $\mathrm{x}_{\mathrm{C}}^{-}$plays an important role in maintaining elevated intracellular levels of glutathione and serves as a potential therapeutic target for a number of ocular diseases.

\section{EFFECTS OF $\mathrm{H}_{2} \mathrm{~S}$ ON CYSTINE/GLUTAMATE ANTIPORTER (SYSTEM $\mathrm{X}_{\mathrm{C}}^{-}$) IN OCULAR TISSUES}

In the $\mathrm{CNS}, \mathrm{H}_{2} \mathrm{~S}$ demonstrates cytoprotective effect by protecting neurons and astrocytes, major type of glial cells from oxidative stress (Kimura, 2011a,b). $\mathrm{H}_{2} \mathrm{~S}$ enhances the activity of system $\mathrm{x}_{\mathrm{C}}^{-}$ and thus significantly increases the transport of cystine into neurons to increase the levels of substrate cysteine, for glutathione synthesis. Even in the presence of glutamate, $\mathrm{H}_{2} \mathrm{~S}$ significantly reverses the inhibition of cystine transport by glutamate (Kimura and Kimura, 2004). Based on the conclusions from these studies (Kimura and Kimura, 2004; Kimura, 2011a,b) in CNS, it will be interesting to investigate the effect of $\mathrm{H}_{2} \mathrm{~S}$ on system $\mathrm{x}_{\mathrm{C}}^{-}$ transporter in astrocytes and muller cells in retina under oxidative stress. Since, muller cells are the primary sites of glutathione localization in the retina, and the retina is extremely vulnerable to oxidative stress, understanding the function of $\mathrm{H}_{2} \mathrm{~S}$ on system $\mathrm{x}_{\mathrm{C}}^{-}$in muller cells could play a pivotal role in protecting the retina from a variety of retinal diseases, such as diabetic retinopathy, age-related macular degeneration, and glaucoma. In the eye, there is evidence from few studies that demonstrate an increase in $\mathrm{GSH}$ production, following application of $\mathrm{H}_{2} \mathrm{~S}$ releasing drugs such as ACS67, ACS1. Although the mechanism of action is not clear, the authors suggest that intracellular cysteine levels are enhanced indirectly to form GSH by $\mathrm{H}_{2} \mathrm{~S}$ stimulation of glutamate/cystine antiporters (Sparatore et al., 2009; Perrino et al., 2009; Osborne et al., 2010). Moreover, as mentioned above, a study by Opere and Ohia (1997) had demonstrated the inhibitory action of $\mathrm{H}_{2} \mathrm{~S}$ donors on glutamatergic transmission in mammalian retinae. So, it is plausible that $\mathrm{H}_{2} \mathrm{~S}$ donors can render there cytoprotective effects by upregulating system $\mathrm{x}_{\mathrm{C}}^{-}$transporter in the retina and thereby increasing the production of glutathione. As the exact mechanism of action needs to be investigated, there is very demanding need to understand the potential role of $\mathrm{H}_{2} \mathrm{~S}$ on the system $\mathrm{x}_{\mathrm{C}}^{-}$transporter in the eye.

\section{CYSTEINE TRANSPORTER IN OCULAR TISSUES}

Cysteine transporters are widely distributed in various cell types including the muller cells of retina. Cysteine transporters readily import cysteine into the cell for direct conversion to glutathione

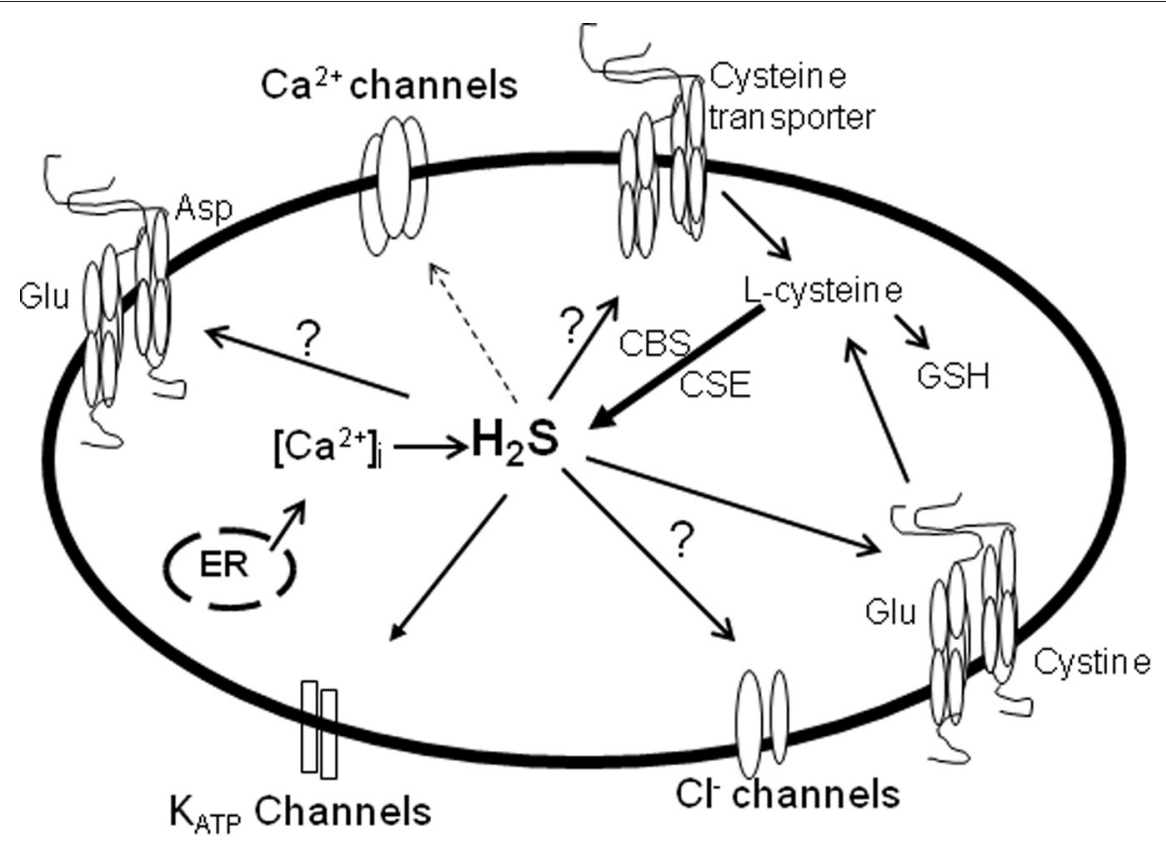

FIGURE 2 | The effects of $\mathrm{H}_{2} \mathrm{~S}$ on ion channels and transporters in the eye. Solid arrow, stimulatory; dotted arrow, inhibitory. Studies on the effects of ion channels and transporters in the eye and/or their interaction with $\mathrm{H}_{2} \mathrm{~S}$ is lacking. $\mathrm{H}_{2} \mathrm{~S}$ which is formed by $\mathrm{CBS}$ and CSE activities, stimulates $\mathrm{K}_{\text {ATP }}$ channels and the cystine/glutamate antiporter thereby regulating ocular smooth muscle relaxation, neurotransmitter release and oxidant/antioxidant balance (solid arrow). The production of $\mathrm{H}_{2} \mathrm{~S}$ can be regulated by intracellular $\mathrm{Ca}^{2+}$, and in turn $\mathrm{H}_{2} \mathrm{~S}$ can suppress $\mathrm{Ca}^{2+}$ channels to exert its neuronal effects (dotted arrow). Whether $\mathrm{H}_{2} \mathrm{~S}$ activates or inhibits glutamate aspartate transporter, cysteine transporter and $\mathrm{Cl}^{-}$channels remains to be determined. 
(Bringmann et al., 2009; Mathai et al., 2009; Kimura, 2010). So far only one study by Kimura (2010) on brain cortex has shown the effect of $\mathrm{H}_{2} \mathrm{~S}$ on cysteine transporters. The study demonstrates that $\mathrm{H}_{2} \mathrm{~S}$ (acting as a reducing agent) reduces cystine into cysteine in the extracellular space and makes cells efficiently transport cysteine into cells for GSH production. Moreover authors state that, the contribution of cysteine transport to the production of GSH is much greater than that of cystine transport. This production of GSH is further enhanced by $\mathrm{H}_{2} \mathrm{~S}$ under conditions of oxidative stress caused by excessive glutamate toxicity. To the best of our knowledge there is a lack of studies on cysteine transporters in the eye and no evidence of the effect of $\mathrm{H}_{2} \mathrm{~S}$ on these transporters in ocular tissues. Although the production of $\mathrm{H}_{2} \mathrm{~S}$ in the eye is not well understood as there is only one study, from our laboratory showing that this gasotransmitter is endogenously produced in ocular tissues (Kulkarni et al., 2011), it is possible that the release of $\mathrm{H}_{2} \mathrm{~S}$ may regulate the transport of cysteine in ocular tissues, thus facilitating the production of GSH. This increase in the levels of GSH by $\mathrm{H}_{2} \mathrm{~S}$ may contribute to the potential protective effect of $\mathrm{H}_{2} \mathrm{~S}$.

\section{REFERENCES}

Abe, K., and Kimura, H. (1996). The possible role of hydrogen sulfide as an endogenous neuromodulator. $J$. Neurosci. 16, 1066-1071.

Arriza, J. L., Eliasof, S., Kavanaugh, M. P., and Amara, S. G. (1997). Excitatory amino acid transporter 5, a retinal glutamate transporter coupled to a chloride conductance. Proc. Natl. Acad. Sci. U.S.A. 94, 4155-4160.

Ashcroft, F. M., and Gribble, F. M. (1999). ATP-sensitive K+ channels and insulin secretion: their role in health and disease. Diabetologia 42, 903-919.

Bauer, C. K., Schafer, R., Schiemann, D., Reid, G., Hanganu, I., and Schwarz, J. R. (1999). A functional role of the erg-like inward-rectifying $\mathrm{K}+$ current in prolactin secretion from rat lactotrophs. Mol. Cell. Endocrinol. 148, 37-45.

Berridge, M. J. (2005). Unlocking the secrets of cell signaling. Annu. Rev. Physiol. 67, 1-21.

Biermann, J., Lagreze, W. A., Schallner, N., Schwer, C. I., and Goebel, U. (2011). Inhalative preconditioning with hydrogen sulfide attenuated apoptosis after retinal ischemia/reperfusion injury. Mol. Vis. 17, 1275-1286.

Blaug, S., Quinn, R., Quong, J., Jalickee, S., and Miller, S. S. (2003). Retinal pigment epithelial function: a role for CFTR? Doc. Ophthalmol. 106, 43-50.

Bogeski, I., Kappl, R., Kummerow, C., Gulaboski, R., Hoth, M., and Niemeyer, B. A. (2011). Redox regulation of calcium ion channels: chemical and physiological aspects. Cell Calcium 50, 407-423.

Bridges, C. C., Kekuda, R., Wang, H., Prasad, P. D., Metha, P., Huang, W., Smith, S. B., and Ganapathty, V. (2001). Structure, function, and regulation of human cystine/glutamate transporter in retinal pigment epithelial cells. Invest. Ophthalmol. Vis. Sci. 42, 47-54.

Bringmann, A., Biedermann, B., Schnurbusch, U., Enzmann, V., Faude, F., and Reichenbach, A. (2000). Age- and disease-related changes of calcium channelmediated currents in human Muller glial cells. Invest. Ophthalmol. Vis. Sci. 41, 2791-2796.

Bringmann, A., Pannicke, T., Biedermann, B., Francke, M., Landiev, I., Grosche, J., Wiedemann, P., Albrecht, J., and Reichenbach, A. (2009). Role of retinal glial cells in neurotransmitter uptake and metabolism. Neurochem. Int. 54, 143-160.

Carafoli, E. (2005). Calcium-a universal carrier of biological signals. Delivered on 3 July 2003 at the special FEBS meeting in Brussels. FEBS J. 272, 1073-1089.

Chen, S., and Sears, M. (1997). A low conductance chloride channel in the basolateral membranes of the non-pigmented ciliary epithelium of the rabbit eye. Curr. Eye Res. 16, 710-718.

Cheng, Y., Ndisang, J. F., Tang, G., Cao, K., and Wang, R. (2004). Hydrogen sulfide-induced relaxation of resistance mesenteric artery beds of rats. Am. J. Physiol. Heart Circ. Physiol. 287, H2316-H2323.

\section{CONCLUDING REMARKS}

Current evidence suggests that ion channels and transporters are present in ocular tissues and are involved in the regulation of vital cellular functions related to vision processes (Figure 2). However, the interaction of these signaling cascades with $\mathrm{H}_{2} \mathrm{~S}$ in the eye is lacking. Clearly, there exists ample evidence that portrays the critical role $\mathrm{H}_{2} \mathrm{~S}$ plays in physiological and pathophysiological processes in the human body. Furthermore, there is enough data that demonstrates that $\mathrm{H}_{2} \mathrm{~S}$ targets different ion channels and transporters to modulate varied physiological functions in the central nervous and cardiovascular systems. Our current knowledge of such interactions in these systems should help facilitate research targeted on investigating the neuromodulatory role of $\mathrm{H}_{2} \mathrm{~S}$ in the eye and its interaction with ion channels and transporters that are play pivotal roles in the preservation of vision. Indeed, future studies are warranted to examine the pharmacological effects of $\mathrm{H}_{2} \mathrm{~S}$ on different types of ion channels and transporters in ocular tissues. Altered effects of $\mathrm{H}_{2} \mathrm{~S}$ on ion channels and transporters, under different pathophysiological conditions in the eye also calls for intensive investigation.

Cooper, K., Rae, J. L., and Dewey, J. (1991). Inwardly rectifying potassium current in mammalian lens epithelial cells. Am. J. Physiol. 261, C115-C123.

Copenhagen, D. R., Renteria, R. C., Takaha, K. I., and Krizaj, D. (2002). Glutamate: glutamine cycling supports synaptic transmission in the retina. Invest. Ophthalmol. Vis. Sci. E-Abstract 1945, 43.

Cordeiro, S., Guseva, D., Wulfsen, I., and Bauer, C. K. (2011). Expression pattern of Kv11 (Ether a-go-gorelated gene; erg) $\mathrm{K}+$ channels in the mouse retina. PLoS ONE 6:e29490. doi: 10.1371/journal.pone.0029490

De, L. G., Ruggeri, P., and Macaione, S. (1974). Cystathionase activity in rat tissues during development. Ital. J. Biochem. 23, 371-379.

Do, C. W., Peterson-Yantorno, K., Mitchell, C. H., and Civan, M. M. (2004). cAMP-activated maxi$\mathrm{Cl}(-)$ channels in native bovine pigmented ciliary epithelial cells. Am. J. Physiol. Cell Physiol. 287, C1003-C1011.

Dun, Y., Mysona, B., Van, E. T., Amarnath, L., Ola, M. S., Ganapathy, V., and Smith, S. B. (2006). Expression of the cystineglutamate exchanger (xc-) in retinal ganglion cells and regulation by nitric oxide and oxidative stress. Cell Tissue Res. 324, 189-202.

Duran, C., Thompson, C. H., Xiao, Q., and Hartzell, H. C. (2010). Chloride channels: often enigmatic, rarely predictable. Annu. Rev. Physiol. 72, 95-121.

Edelman, J. L., Loo, D. D., and Sachs, G. (1995). Characterization of potassium and chloride channels in the basolateral membrane of bovine nonpigmented ciliary epithelial cells. Invest. Ophthalmol. Vis. Sci. 36, 2706-2716.

Elrod, J. W., Calvert, J. W., Morrison, J., Doeller, J. E., Kraus, D. W., Tao, L., Jiao, X., Scalia, R., Kiss, L., Szabo, C., Kimura, H., Chow, C. W., and Lefer, D. J. (2007). Hydrogen sulfide attenuates myocardial ischemia-reperfusion injury by preservation of mitochondrial function. Proc. Natl. Acad. Sci. U.S.A. 104, 15560-15565.

Erickson, P. F., Maxwell, I. H., Su, L. J., Baumann, M., and Glode, L. M. (1990). Sequence of cDNA for rat cystathionine gamma-lyase and comparison of deduced amino acid sequence with related Escherichia coli enzymes. Biochem. J. 269, 335-340.

Fiorucci, S., Distrutti, E., Cirino, G., and Wallace, J. L. (2006). The emerging roles of hydrogen sulfide in the gastrointestinal tract and liver. Gastroenterology 131, 259-271.

Hosoki, R., Matsuki, N., and Kimura, H. (1997). The possible role of hydrogen sulfide as an endogenous smooth muscle relaxant in synergy with nitric oxide. Biochem. Biophys. Res. Commun. 237, 527-531.

Hosoya, K., Tomi, M., Ohtsuki, S., Takanaga, H., Saeki, S., Kanai, Y., Endou, H., Naito, M., Tsuruo, T., and Terasaki, T. (2002). Enhancement of L-cystine transport activity and its relation to $\mathrm{xCT}$ gene induction at the blood-brain barrier by diethyl maleate treatment. $J$. Pharmacol. Exp. Ther. 302, 225-231. 
Kanner, B. I. (2006). Structure and function of sodium-coupled GABA and glutamate transporters. $J$. Membr. Biol. 213, 89-100.

Kato, S., Ishita, S., Sugawara, K., and Mawatari, K. (1993). Cystine/glutamate antiporter expression in retinal Muller glial cells: implications for DL-alphaaminoadipate toxicity. Neuroscience $57,473-482$.

Kimura, H. (2002). Hydrogen sulfide as a neuromodulator. Mol. Neurobiol. 26, 13-19.

Kimura, H. (2010). Hydrogen sulfide: from brain to gut. Antioxid. Redox Signal. 12, 1111-1123.

Kimura, H. (2011a). Hydrogen sulfide: its production, release and functions. Amino Acids 41, 113-121.

Kimura, H. (2011b). Hydrogen sulfide: its production and functions. Exp. Physiol. 96, 833-835.

Kimura, H., Nagai, Y., Umemura, K., and Kimura, Y. (2005). Physiological roles of hydrogen sulfide: synaptic modulation, neuroprotection, and smooth muscle relaxation. Antioxid. Redox Signal. 7, 795-803.

Kimura, Y., Dargusch, R., Schubert, D., and Kimura, H. (2006). Hydrogen sulfide protects HT22 neuronal cells from oxidative stress. Antioxid. Redox Signal. 8, 661-670.

Kimura, Y., and Kimura, H. (2004). Hydrogen sulfide protects neurons from oxidative stress. FASEB J. 18, 1165-1167.

Klyce, S. D., and Wong, R. K. (1977). Site and mode of adrenaline action on chloride transport across the rabbit corneal epithelium. J. Physiol. 266, 777-799.

Kofuji, P., Biedermann, B., Siddharthan, V., Raap, M., Iandiev, I., Milenkovic, I., Thomzig, A., Veh, R. W., Bringmann, A., and Reichenbach, A. (2002). Kir potassium channel subunit expression in retinal glial cells: implications for spatial potassium buffering. Glia 39, 292-303.

Kraus, J. P., and Kozich, V. (2001). "Cystathionine B synthase and its deficiency," in Homocysteine in health and disease, eds R. Carmel and D. W. Jacobsen (Cambridge: Cambridge University Press), 223-243.

Kulkarni, K. H., Monjok, E. M., Zeyssig, R., Kouamou, G., Bongmba, O. N., Opere, C. A., Njie, Y. F., and Ohia, S. E. (2009). Effect of hydrogen sulfide on sympathetic neurotransmission and catecholamine levels in isolated porcine irisciliary body. Neurochem. Res. 34, 400-406.
Kulkarni, M., Njie-Mbye, Y. F., Okpobiri, I., Zhao, M., Opere, C. A., and Ohia, S. E. (2011). Endogenous production of hydrogen sulfide in isolated bovine eye. Neurochem. Res. 36, 1540-1545.

Levin, M. H., and Verkman, A. S. (2005). CFTR-regulated chloride transport at the ocular surface in living mice measured by potential differences. Invest. Ophthalmol. Vis. Sci. 46, 1428-1434.

Levy, L. M., Warr, O., and Attwell, D. (1998). Stoichiometry of the glial glutamate transporter GLT-1 expressed inducibly in a Chinese hamster ovary cell line selected for low endogenous $\mathrm{Na}+$-dependent glutamate uptake. J. Neurosci. 18, 9620-9628.

Lim, J. C., and Donaldson, P. J. (2011). Focus on molecules: the cystine/glutamate exchanger (System $\mathrm{x}(\mathrm{c})(-))$. Exp. Eye Res. 92 162-163.

Lim, J., Lam, Y. C., Kistler, J., and Donaldson, P. J. (2005). Molecular characterization of the cystine/glutamate exchanger and the excitatory amino acid transporters in the rat lens. Invest. Ophthalmol. Vis. Sci. 46, 2869-2877.

Llobet, A., Gasull, X., Pales, J., Marti, E., and Gual, A. (2001). Identification of Kir2.1 channel activity in cultured trabecular meshwork cells. Invest. Ophthalmol. Vis. Sci. 42, 2371-2379.

Lo, M., Wang, Y. Z., and Gout, P. W. (2008). The $\mathrm{x}(\mathrm{c})$ - cystine/glutamate antiporter: a potential target for therapy of cancer and other diseases. J. Cell Physiol. 215, 593-602.

Lowicka, E., and Beltowski, J. (2007). Hydrogen sulfide (H2S) - the third gas of interest for pharmacologists. Pharmacol. Rep. 59, 4-24.

Lu, L., Wang, L., and Shell, B. (2003). UV-induced signaling pathways associated with corneal epithelial cell apoptosis. Invest. Ophthalmol. Vis. Sci. 44, 5102-5109.

Lu, M., Hu, L. F., Hu, G., and Bian, J. S. (2008). Hydrogen sulfide protects astrocytes against $\mathrm{H}(2) \mathrm{O}(2)$ induced neural injury via enhancing glutamate uptake. Free Radic. Biol. Med. 45, 1705-1713.

MacDonald, P. E., and Wheeler, M. B. (2003). Voltage-dependent $\mathrm{K}(+)$ channels in pancreatic beta cells: role, regulation and potential as therapeutic targets. Diabetologia 46, 1046-1062.

Martelli, A., Testai, L., Breschi, M. C., Blandizzi, C., Virdis, A., Taddei, S., and Calderone, V. (2010). Hydrogen sulphide: novel opportunity for drug discovery. Med. Res. Rev. doi: 10.1002/med.20234. [Epub ahead of print].

Masi, A., Becchetti, A., RestanoCassulini, R., Polvani, S., Hofmann, G., Buccoliero, A. M., Paglierani, M., Pollo, B., Taddei, G. L., Gallina, P., Di Lorenzo, N., Franceschetti, S., Wanke, E., and Arcangeli, A. (2005). hERG1 channels are overexpressed in glioblastoma multiforme and modulate VEGF secretion in glioblastoma cell lines. Br. J. Cancer 93, 781-792.

Mathai, J. C., Missner, A., Kugler, P., Saparov, S. M., Zeidel, M. L., Lee, J. K., and Pohl, P. (2009). No facilitator required for membrane transport of hydrogen sulfide. Proc. Natl. Acad. Sci. U.S.A. 106, 16633-16638.

Mikami, Y., Shibuya, N., Kimura, Y., Nagahara, N., Yamada, M., and Kimura, H. (2011). Hydrogen sulfide protects the retina from lightinduced degeneration by the modulation of $\mathrm{Ca} 2+$ influx. J. Biol. Chem. 286, 39379-39386.

Monjok, E. M., Kulkarni, K. H., Kouamou, G., McKoy, M., Opere, C. A., Bongmba, O. N., Njie, Y. F. and Ohia, S. E. (2008). Inhibitory action of hydrogen sulfide on muscarinic receptor-induced contraction of isolated porcine irides. Exp. Eye Res. 87, 612-616.

Njie-Mbye, Y. F., Bongmba, O. Y., Onyema, C. C., Chitnis, A., Kulkarni, M., Opere, C. A., LeDay, A. M. and Ohia, S. E. (2010). Effect of hydrogen sulfide on cyclic AMP production in isolated bovine and porcine neural retinae. Neurochem. Res. 35, 487-494.

Njie-Mbye, Y. F., Kulkarni, M., Opere, C. A., and Ohia, S. E. (2012). Mechanism of action of hydrogen sulfide on cyclic AMP formation in rat retinal pigment epithelial cells. Exp. Eye Res. 98, 16-22.

Ohia, S. E., Opere, C. A., Monjok, E. M., Kouamou, G., LeDay, A. M. and Niie-Mbye, Y. F. (2010). Role of hydrogen sulfide production in inhibitory action of L-cysteine on isolated porcine irides. Curr. Eye Res. 35, 402-407.

Opere, C. A., Monjok, E. M., Kulkarni, K. H., Njie, Y. F., and Ohia, S. E. (2009). Regulation of $[(3) \mathrm{h}] \mathrm{d}$ : aspartate release from mammalian isolated retinae by hydrogen sulfide. Neurochem. Res. 34, 1962-1968.

Opere, C. A., and Ohia, S. E. (1997). Role of cyclic AMP in hydrogen peroxide-induced potentiation of sympathetic neurotransmission in the bovine iris. J. Ocul. Pharmacol. Ther. 13, 261-268.

Osborne, N. N., Ji, D., Abdul Majid, A. S., Fawcett, R. J., Sparatore, A., and Del, S. P. (2010). ACS67, a hydrogen sulfide-releasing derivative of latanoprost acid, attenuates retinal ischemia and oxidative stress to RGC-5 cells in culture. Invest Ophthalmol. Vis. Sci. 51, 284-294.

Perrino, E., Uliva, C., Lanzi, C., Soldato, P. D., Masini, E., and Sparatore, A. (2009) New prostaglandin derivative for glaucoma treatment. Bioorg. Med. Chem. Lett. 19, 1639-1642.

Persa, C., Osmotherly, K., Chao-Wei, C. K., Moon, S., and Lou, M. F. (2006). The distribution of cystathionine beta-synthase (CBS) in the eye: implication of the presence of a trans-sulfuration pathway for oxidative stress defense. Exp. Eye Res. 83, 817-823.

Pong, W. W., Stouracova, R., Frank, N., Kraus, J. P., and Eldred, W. D. (2007). Comparative localization of cystathionine beta-synthase and cystathionine gamma-lyase in retina: differences between amphibians and mammals. J. Comp. Neurol. 505, 158-165.

Pow, D. V., and Barnett, N. L. (1999). Changing patterns of spatial buffering of glutamate in developing rat retinae are mediated by the Muller cell glutamate transporter GLAST. Cell Tissue Res. 297, 57-66.

Pow, D. V., and Barnett, N. L. (2000). Developmental expression of excitatory amino acid transporter 5, a photoreceptor and bipolar cell glutamate transporter in rat retina. Neurosci. Lett. 280, 21-24.

Puro, D. G., Hwang, J. J., Kwon, O. J., and Chin, H. (1996). Characterization of an L-type calcium channel expressed by human retinal Muller (glial) cells. Brain Res. Mol. Brain Res. 37, 41-48.

Puro, D. G., and Mano, T. (1991). Modulation of calcium channels in human retinal glial cells by basic fibroblast growth factor: a possible role in retinal pathobiology. $J$. Neurosci. 11, 1873-1880.

Qu, K., Lee, S. W., Bian, J. S., Low, C. M., and Wong, P. T. (2008) Hydrogen sulfide: neurochemistry and neurobiology. Neurochem. Int. $52,155-165$.

Rae, J. L. (1985). The application of patch clamp methods to ocular epithelia. Curr. Eye Res. 4, 409-420.

Rae, J. L. (1986). Potassium channels from chick lens epithelium. Fed. Proc. 45, 2718-2722.

Rae, J. L., Dewey, J., Rae, J. S., Nesler, M., and Cooper, K. (1990). Single potassium channels in corneal epithelium. Invest. Ophthalmol. Vis. Sci. 31, 1799-1809.

Rae, J. L., and Farrugia, G. (1992). Whole-cell potassium current in 
rabbit corneal epithelium activated by fenamates. J. Membr. Biol. 129, 81-97.

Rauen, T., Rothstein, J. D., and Wassle, H. (1996). Differential expression of three glutamate transporter subtypes in the rat retina. Cell Tissue Res. 286, 325-336.

Rauen, T., and Kanner, B. I. (1994). Localization of the glutamate transporter GLT-1 in rat and macaque monkey retinae. Neurosci. Lett. 169, 137-140.

Reigada, D., and Mitchell, C. H. (2005). Release of ATP from retinal pigment epithelial cells involves both CFTR and vesicular transport. Am. J. Physiol. Cell Physiol. 288, C132-C140.

Rhodes, J. D., and Sanderson, J. (2009). The mechanisms of calcium homeostasis and signalling in the lens. Exp. Eye Res. 88, 226-234.

Roderick, C., Reinach, P. S., Wang, L., and $\mathrm{Lu}, \mathrm{L}$. (2003). Modulation of rabbit corneal epithelial cell proliferation by growth factor-regulated $\mathrm{K}(+)$ channel activity. J. Membr. Biol. 196, 41-50.

Rose, E. M., Koo, J. C., Antflick, J. E., Ahmed, S. M., Angers, S., and Hampson, D. R. (2009). Glutamate transporter coupling to Na, K-ATPase. J. Neurosci. 29, 8143-8155.

Shibuya, N., Mikami, Y., Kimura, Y., Nagahara, N., and Kimura, H. (2009a). Vascular endothelium expresses 3-mercaptopyruvate sulfurtransferase and produces hydrogen sulfide. J. Biochem. 146, 623-626.

Shibuya, N., Tanaka, M., Yoshida, M., Ogasawara, Y., Togawa, T., Ishii, K., and Kimura, H. (2009b). 3Mercaptopyruvate sulfurtransferase produces hydrogen sulfide and bound sulfane sulfur in the brain. Antioxid. Redox Signal. 11, 703-714.

Shiue, M. H., Gukasyan, H. J., Kim, K. J., Loo, D. D., and Lee, V.
H. (2002). Characterization of cyclic AMP-regulated chloride conductance in the pigmented rabbit conjunctival epithelial cells. Can. J. Physiol. Pharmacol. 80, 533-540.

Shuttleworth, T. J. (1997). Intracellular $\mathrm{Ca} 2+$ signalling in secretory cells. $J$. Exp. Biol. 200, 303-314.

Sivarajah, A., McDonald, M. C., and Thiemermann, C. (2006). The production of hydrogen sulfide limits myocardial ischemia and reperfusion injury and contributes to the cardioprotective effects of preconditioning with endotoxin, but not ischemia in the rat. Shock 26, 154-161.

Sparatore, A., Perrino, E., Tazzari, V., Giustarini, D., Rossi, R., Rossoni, G., Erdmann, K., Schroder, H., and Del Soldato, P. (2009). Pharmacological profile of a novel $\mathrm{H}(2)$ S-releasing aspirin. Free Radic. Biol. Med. 46, 586-592.

Stipanuk, M. H., and Beck, P. W. (1982). Characterization of the enzymic capacity for cysteine desulphhydration in liver and kidney of the rat. Biochem. J. 206, 267-277.

Sun, X. C., and Bonanno, J. A. (2002). Expression, localization, and functional evaluation of CFTR in bovine corneal endothelial cells. Am. J. Physiol. Cell Physiol. 282, C673-C683.

Swaroop, M., Bradley, K., Ohura, T., Tahara, T., Roper, M. D., Rosenberg, L. E., and Kraus, J. P. (1992). Rat cystathionine beta-synthase. Gene organization and alternative splicing. J. Biol. Chem. 267, 11455-11461.

Szabo, C. (2007). Hydrogen sulphide and its therapeutic potential. Nat. Rev. Drug Discov. 6, 917-935.

Tang, G., Wu, L., and Wang, R. (2010). Interaction of hydrogen sulfide with ion channels. Clin. Exp. Pharmacol. Physiol. 37, 753-763.
Tomi, M., Hosoya, K., Takanaga, H., Ohtsuki, S., and Terasaki, T. (2002). Induction of xCT gene expression and L-cystine transport activity by diethyl maleate at the inner bloodretinal barrier. Invest. Ophthalmol. Vis. Sci. 43, 774-779.

Turner, H. C., Bernstein, A., and Candia, O. A. (2002). Presence of CFTR in the conjunctival epithelium. Curr. Eye Res. 24, 182-187.

Verkman, A. S., and Galietta, L. J. (2009). Chloride channels as drug targets. Nat. Rev. Drug Discov. 8, 153-171.

Ward, M. M., Jobling, A. I., Puthussery, T., Foster, L. E., and Fletcher, E. L. (2004). Localization and expression of the glutamate transporter, excitatory amino acid transporter 4 , within astrocytes of the rat retina. Cell. Tissue Res. 315, 305-310.

Warth, R. (2003). Potassium channels in epithelial transport. Pflugers Arch. 446, 505-513.

Webb, G. D., Lim, L. H., Oh, V. M., Yeo, S. B., Cheong, Y. P., Ali, M. Y., El Oakley, R., Lee, C. N., Wong, P. S., Caleb, M. G., Salto-Tellez, M., Bhatia, M., Chan, E. S., Taylor, E. A., and Moore, P. K. (2008). Contractile and vasorelaxant effects of hydrogen sulfide and its biosynthesis in the human internal mammary artery. $J$. Pharmacol. Exp. Ther. 324, 876-882.

Williams, R. J. (1974). Calcium ions: their ligands and their functions. Biochem. Soc. Symp. 39, 133-138.

Wimmers, S., Karl, M. O., and Strauss, O. (2007). Ion channels in the RPE. Prog. Retin. Eye Res. 26, 263-301.

Wolosin, J. M., and Candia, O. A. (1987). Cl- secretagogues increase basolateral $\mathrm{K}+$ conductance of frog corneal epithelium. Am. J. Physiol. 253, C555-C560.

Yamada, K., and Inagaki, N. (2005). Neuroprotection by KATP channels. J. Mol. Cell. Cardiol. 38, 945-949.

Zerangue, N., and Kavanaugh, M. P. (1996). Flux coupling in a neuronal glutamate transporter. Nature 383, 634-637.

Zhang, H., Wong, C. L., Shan, S. W., Li, K. K., Cheng, A. K., Lee, K. L., Ge, J., To, C. H., and Do, C. W. (2011). Characterisation of $\mathrm{Cl}(-)$ transporter and channels in experimentally induced myopic chick eyes. Clin. Exp. Optom. 94, 528-535.

Zhao, W., Zhang, J., Lu, Y., and Wang, R. (2001). The vasorelaxant effect of $\mathrm{H}(2) \mathrm{S}$ as a novel endogenous gaseous $\mathrm{K}(\mathrm{ATP})$ channel opener. EMBO J. 20, 6008-6016.

Zou, J. Y., and Crews, F. T. (2005) TNF alpha potentiates glutamate neurotoxicity by inhibiting glutamate uptake in organotypic brain slice cultures: neuroprotection by NF kappa B inhibition. Brain Res. 1034, 11-24.

Conflict of Interest Statement: The authors declare that the research was conducted in the absence of any commercial or financial relationships that could be construed as a potential conflict of interest.

Received: 16 May 2012; paper pending published: 25 May 2012; accepted: 08 July 2012; published online: 25 July 2012. Citation: Njie-Mbye YF, Opere CA, Chitnis $M$ and Ohia SE (2012) Hydrogen sulfide: role in ion channel and transporter modulation in the eye. Front. Physio. 3:295. doi: 10.3389/ fphys.2012.00295

This article was submitted to Frontiers in Membrane Physiology and Biophysics, a specialty of Frontiers in Physiology. Copyright (c) 2012 Njie-Mbye, Opere, Chitnis, Ohia. This is an open-access article distributed under the terms of the Creative Commons Attribution License, which permits use, distribution and reproduction in other forums, provided the original authors and source are credited and subject to any copyright notices concerning any third-party graphics etc. 